This is the post-peer reviewed final draft version of the following article: Balcells, I., Molla, A. \& Heeks, R. "Adding clicks to bricks: a case study of e-commerce adoption by a Catalan small retailer", European Journal of Information Systems, 15(4), 424438, 2006, which has been published in final form at: http://www.palgravejournals.com/ejis/journal/v15/n4/full/3000623a.html

\title{
Adding Clicks to Bricks : A Case Study of E-Commerce Adoption by a Catalan Small Retailer
}

\author{
Isaac Balcells \\ Project Manager, Amec Spie Spain \\ isaac.balcells@aaupc.upcnet.es
}
Alemayehu Molla (Corresponding Author)
alemayehu.molla@rmit.edu.au
School of Business Information Technology
RMIT University
Level 17, 239-251 Bourke Street
Melbourne VIC 3000
Australia
Tel: +613-9925-5803
Fax: $+613-9925-5850$

\author{
Richard Heeks \\ IDPM \\ University of Manchester, UK \\ richard.heeks@manchester.ac.uk
}

\begin{abstract}
This paper explores why and how one small business adopted e-commerce. Understanding the importance of a chronological perspective, the paper first develops a conceptual model that explicitly incorporates both different stages of e-commerce functionality and the different phases of the e-commerce adoption process. It relates these to a set of adoption factors classified into contextual, organisational, managerial, and e-commerce-specific categories. The paper explores and illustrates the model with the case history of a wine retailing microenterprise based in Catalonia, Spain that
\end{abstract}


ultimately failed. The presented model is found to provide a workable basis for analysis, and the findings demonstrate the way in which different factors affect different phases of the adoption process. More generally, it finds expected contextual factors such as competitors or customers to have little impact on adoption, which is affected more by informal processes and social relations. The paper ends by questioning the simplicity of progressive e-commerce models that fail to incorporate abandonment of the technology, and fail to account for the lack of business value that some e-commerce projects deliver. The case's chronological approach also identifies the path-dependent manner in which earlier decisions impact later e-commerce trajectories, with short-term, subjective decisions potentially constraining e-commerce in the longer term.

Keywords: E-commerce Adoption, Microenterprise, SMEs, Case Study, Europe, Spain

\section{INTRODUCTION}

The purpose of this paper is to analyse e-commerce adoption in small firms (defined in the European Union as those with less than 50 employees and annual turnover of less than $€ 10 \mathrm{~m}$ ), focusing particularly on the factors and phases that underpin the adoption process. The paper adopts a case study approach, based on the case of a wine retailer in Catalonia, Spain.

A small firm focus was selected because such firms combine an economic significance with particular challenges to e-commerce adoption. In Europe, for example, they represent $99 \%$ of all firms (EC, 2003). They also contribute 
disproportionately to employment and employment generation: globally, small firms provide between half and two-thirds of all jobs and in the focal country, Spain, smalland medium-sized enterprises (SMEs) generated 80\% of all new jobs between 1996 and 2000 (Baldwin et al., 2001; Dirección General de Política de la Pyme, 2002). Small firms are also credited as key forums for apprenticeship, as principal sources of innovation, and as "shock absorbers" during periods of economic transition (Palvia, 1996; Baldwin et al., 2001; Harvie \& Lee, 2002).

Given this economic significance, governments - like entrepreneurs themselves have been keen to identify strategies to boost the growth and competitiveness of small business. One such strategy has been promotional policies to support greater use of ecommerce, $(\mathrm{EC}, 2003)$. The result of these policies plus entrepreneurial actions has been mixed. On the one hand, there are growing rates of e-commerce adoption among small businesses worldwide (Poon \& Swatman, 1999; Mirchandani \& Motwani, 2001). Yet these same sources also note the majority of such firms have yet to adopt e-commerce or have not moved beyond entry-level adoption.

Research has followed these trends. Some work has focused on general categorisation of e-commerce in small enterprise (Webb \& Sayer, 1998; Chen et al., 2003) or sought to understand the potential benefits of e-commerce to these firms' efficiency and competitiveness (Auger \& Gallaugher, 1997; Daniel \& Myers, 2000; Mehta \& Shah, 2001; Ibbotson \& Fahy; 2004). The limited nature, or variability, of e-commerce adoption in small enterprise has also been investigated through research studying factors that facilitate or inhibit adoption (Poon \& Swatman, 1999; 
Riemenschneider \& McKinney 2001; Daniel \& Grimshaw, 2002; Seyal \& Rahman, 2003; Mustaffa \& Beaumont, 2004).

These works have made valuable contributions to our understanding of e-commerce adoption in small firms but we perceived some limitations of past research that motivated our own work. These include (1) the tendency to "black box" the process of e-commerce adoption using a dichotomous scale that only differentiates ecommerce adopters (or those with an intention to adopt) from non-adopters, (2) the dominance of a survey-based approach with limited ability to provide rich explanations of how and why small firms adopt e-commerce over time, (3) the poor representation of European small firms in this field of study, and (4) the skew of sample selection in terms of enterprise size and survival, with under-representation of microentrprises (defined in the European Union as those with less than ten employees and annual turnover of less than $€ 2 \mathrm{~m}$ ) and of failed enterprises in the current literature.

This study therefore aims to address the above gaps and offer deeper insights into the e-commerce adoption process in small firms. We chose to study a microenterprise that eventually failed on the understanding that it represents a far better archetype for enterprise than the unrepresentatively large and surviving firms that are more typically the focus for small enterprise e-commerce research. The next section reviews the conceptual foundations for our work, synthesising ideas from past literature to produce a new chronological model. After detailing the research method, we then outline the case enterprise and describe the history of its involvement with ecommerce. This involvement is then analysed using the conceptual model and the 
paper ends with a set of theoretical and practical implications drawn from the case analysis.

\section{CONCEPTUAL FOUNDATIONS}

\section{Review of Past Research on E-Commerce Adoption in Small Firms}

To avoid "black boxing" e-commerce adoption, we drew on the fact that e-commerce is a particular example of innovation (Kendall et al., 2001; Travica, 2002). Innovation theory suggests that the adoption process in organisations passes through several phases, which are typically labelled initiation, decision and implementation (Thompson, 1965; Rogers, 1995). E-commerce adoption is therefore seen to start when small firm managers become aware of e-commerce and evaluate its adoption potential. Following an adoption decision, the process then continues to implementation of the e-commerce application. Existing e-commerce models tend to assume a direct relation between implementation and benefits (e.g. Daniel \& Grimshaw, 2002). In line with the evidence on information systems failure, though, we wish to add in a potential for lack of benefits or even abandonment of the application (Sauer, 1999).

Experience shows that e-commerce adoption is not necessarily a one-time activity. Instead small firms can be seen gradually developing more complex, more integrated e-commerce capabilities (Daniel et al., 2002; Chen et al., 2003). At the initial stage, they have an informational functionality with basic e-mail capability and Web presence (Sillince et al., 1998). At the next stage, interactional and then transactional functionalities are added to the Web site (Zhu \& Kraemer, 2002). Alongside, e- 
commerce is likely to become more integrated into the work of the small firm, requiring changes to - and ultimately transformation of - related business processes and back-office information systems (Eduard, 2001). Each one of these stages will see a cycle of the adoption phases described above.

Turning to understand the factors that affect this adoption process, we find a plethora of possibilities on offer from existing literature. To help understand this literature, we drew from Tornatzky and Fleischer's (1990) technology-organisation-environment framework and imposed a categorisation on the factors identified, organising them under four headings:

- Contextual factors, that lay outside the boundaries of the focal enterprise.

- Organisational factors, that related to the resources, processes and structure of the focal enterprise.

- Managerial factors, given the key role played by entrepreneurial owner-managers in small enterprise.

- E-commerce-specific factors, that related to the nature of the application and its impact.

Contextual factors may influence e-commerce somewhat more than internal information systems because of this application's necessary network externalities $(\mathrm{Au}$ \& Kaufman, 2001). For example, the sector within which a small firm operates can either motivate or discourage e-commerce adoption (Moodley 2003). The sector shapes the information intensity of the firm's process and output; a factor positively correlated with adoption of e-commerce (Iacovou et al., 1995; Poon \& Swatman, 1999). 
In addition, the sector defines the nature and rivalry of industry competitiveness and the power of market forces. This is significant because pressure from customers, competitors, suppliers and trading partners often leads to e-commerce adoption (Keeling et al., 2000; Loforte \& Love, 2003). For instance, in the retail sector, where e-commerce represents an attractive distribution channel, a critical mass of Internetusing customers plus other aspects of consumer e-readiness such as trust of online transactions have been seen to influence small companies' implementation of ecommerce (Auger \& Gallaugher, 1997; Van Akkeren \& Cavaye, 1999). In addition, small enterprises whose main rivals are online can find themselves forced to adopt ecommerce as a defensive strategy to avoid losing competitiveness (Poon \& Swatman, 1999).

Another contextual influence is the enterprise's geographical location (Webb \& Sayer, 1998; Daniel \& Grimshaw, 2002). Countries or regions have differing levels of factors such as financial, technological and institutional e-readiness (Dutta et al., 2003). These affect both consumer and business adoption of e-commerce (Poon, 2000; Beveren \& Thomson, 2002).

Organisationally, small firms have some distinct characteristics that either facilitate or inhibit e-commerce. For example, smaller firms tend to be structurally less complex than larger firms; something that can facilitate fast decision making and innovation (Daniel \& Grimshaw, 2002). Small organisations may also more readily be able to make the kind of internal changes to processes and structures that are seen 
as necessary to deliver the benefits of later stages of e-commerce capability (Eduard, 2001; Chen et al., 2003).

On the other hand, small size tends to restrict access to relevant innovation/adoptionrelated resources (human, technological and financial). Hence, the findings from previous studies showing factors such as lack of e-commerce competencies (and lack of access to training) (Riemenschneider \& McKinney, 2001); limited IT base (Iacovou et al., 1995); and high cost of developing and maintaining systems (Sillince et al., 1998) as either inhibiting e-commerce adoption or limiting its functionality in small businesses. The resource limitations of smaller firms mean that external change agents with access to resources - government departments, industry associations, solution providers, etc. - often have a significant influence on e-commerce adoption. The change agents' role can include anything from simple awareness-raising through facilitating adoption of particular e-commerce solutions to designing the modus operandi of the new e-business (Brown \& Lockett, 2001; Elsammani et al., 2004).

In terms of managerial factors, smaller firms also tend to differ from larger firms. They are characterised by highly centralised management (Longenecker et al., 1994; Mirchandani \& Motwani, 2001) and by an ill-defined distinction between owner and management (Cloete et al., 2002). Hence, the tendency for one or two individuals in an owner-manager role to have a disproportionate impact on e-commerce adoption. The enthusiasm and commitment of these individuals is found to have a significant influence on the adoption process (Harrison et al., 1997; Grandon \& Pearson, 2003). So, too, does their level of e-commerce skills and their attitude to innovation. 
Finally, the specific nature of e-commerce as a technology has been found to affect its adoption. The trialability ("the degree to which an innovation may be experimented with on a limited basis") of the application compared to other IT applications has encouraged its adoption (Seyal \& Rahman, 2003:12). So, also, have the technical advances which are reducing the skill levels required to build at least the first, entrylevel stage of e-commerce. These have allowed small entrepreneurs to get a foot on the e-commerce ladder without outside assistance (Elsammani \& Scown, 2000).

Entrepreneurial adoption is also impacted by the touted potential of e-commerce to increase national and global visibility (Alexander, 1999), to expand market reach (Daniel \& Grimshaw, 2002), to save on market coordination and transaction costs (Mehta \& Shah, 2001), and to enhance business information access and exchange (Dutta \& Evrard, 1999). Following the tenets of theory on the diffusion of innovation (Rogers, 1995), rather than any objective measures of the technology, it is entrepreneurs' perceptions of e-commerce that discriminate e-commerce adopters from non-adopters: perceptions of its trialability, perceptions of the benefits it offers relative to other technologies; perceptions of its compatibility with their work, and so on (Thong, 1999; Kendall et al., 2001; Mirchandani \& Motwani, 2001; Riemenschneider \& McKinney, 2001; Cloete et al., 2002; Grandon \& Pearson, 2003; Lertwongsatien \& Wongpinunwatana, 2003). Continuation of investment to expand beyond entry-level stages of functionality may depend on actual benefits from previous e-commerce stages though, again, decisions will be guided by perceptions (Daniel \& Myers, 2000; Loforte \& Love, 2003; Elsammani et al., 2004). 


\section{Conceptual Framework}

On the basis of this literature review, we therefore built a conceptual framework that would form the basis for our case study, as shown in Figure 1. The framework integrated the three main elements identified from the literature review: i) a set of progressive stages of e-commerce adoption within each of which would be ii) the three phases of the adoption process (initiate, decide, implement) but with a potential for application failure; and iii) a set of factors that would affect the adoption phases at each stage, grouped into the contextual, organisational, managerial, and e-commercespecific (COME) categories. In addition, where it occurs, progression to the next ecommerce stage would be influenced by the outcome of the previous stage. 
Figure 1. A Conceptual Framework for the E-Commerce Adoption Process

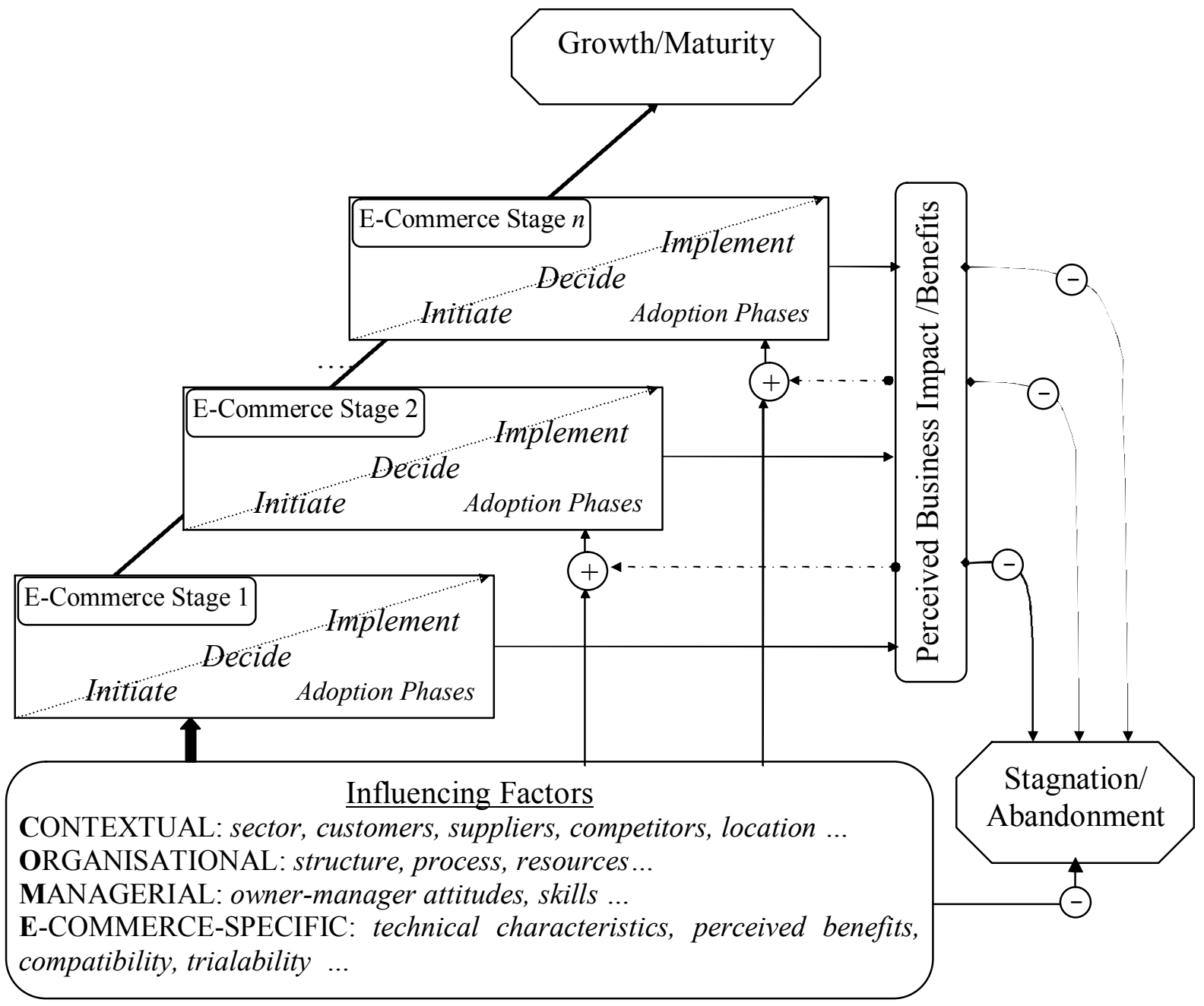

Previous frameworks have related factors to small firms' adoption of e-commerce (e.g. Daniel \& Grimshaw, 2002) or of information systems generally (e.g. Thong, 1999; Levy \& Powell, 2000). We do not see this new model as different to these earlier frameworks specifically because of its synthesis or testing of adoption factors. The factors presented above reflect a broad literature survey of archetypical variables, but they should not be seen as a necessarily exhaustive list of all possible influences on the e-commerce adoption process. 
Where this conceptual model more particularly differentiates itself is in providing a new longitudinal perspective on e-commerce; seeing it as a process of phases within stages that are mutually influential and which may not necessarily result in application success (or even organisational survival). Thus, while both factors and categories within our framework will be used to examine the enterprise case study, a key focus of interest will also be the unfolding of adoption over time.

\section{RESEARCH METHODS}

The purpose of our study is to illustrate how and why different contextual, organisational, managerial and e-commerce-specific factors affect the process of ecommerce adoption in a small firm. There was therefore a prima facie case for using a single case study method since this supports the kind of approach we sought: one that was exploratory in testing out a new conceptual framework; one that would provide sufficient richness of content and context to be explanatory; and one that would produce a descriptive and illustrative story (Benbasat et al., 1987; Eisenhardt, 1991; Yin, 2003). Single case methods are advocated for these purposes for small firm work generally (Chetty, 1996; Perren \& Ram, 2004) and, more specifically, for study of the implementation and impacts of e-commerce in small enterprise (Poon \& Huang, 2004).

The background for case selection was the three-year working experience of author

$* * * * * * *$ in the focal enterprise; working as the main implementer of e-commerce and as the son of the owner-manager. However, we only proceeded with case analysis 
because this enterprise met our pre-set criteria formed on the basis of literature review discussed in the Introduction. The case site satisfied the European Union classification for a small business and, as both an ultimately-failed enterprise and a microenterprise, it was typical of the majority of small enterprises. The abandonment of the enterprise's e-commerce system was, if not typical, then an outcome whose prevalence is not well represented in literature to date. It is unclear whether or not this enterprise's decision to adopt e-commerce is typical of enterprises with less than ten employees, but the presence of adoption does neutralise the greater bias to nonadoption seen with smaller sizes of enterprise (Sillince et al., 1998; Thong, 1999).

We drew on multiple sources of evidence, reflecting the recommendation that triangulation be used for the compilation of e-commerce cases in small firms (Poon \& Huang, 2004). Initial pilot work was conducted in spring of 2003 while the enterprise was still operating but the main focus of data gathering came in autumn of that year, following enterprise closure. Detailed interviews were held with the owner-manager the operations manager and the e-commerce developer of the enterprise. Pertinent internal documentation such as annual reports, financial statements, minutes, Web design drafts, etc., were collected and evaluated. This process, in itself, provided an in-depth insight into the firm and its process of e-commerce adoption but, as per norms of triangulation, this was supplemented by observational data (Stoecker, 1991; Yin, 2003).Because of the intimate involvement of one author with the case, we were able to get a depth of retrospective observation data going well beyond that which interview or questionnaire can offer. To control for bias and errors (both observational and retrospective), the other two authors reviewed and questioned the observational data (Golden, 1992). 
This process of data collection was guided by the COME framework and, once the data had been initially reviewed, the interpretive lens of the conceptual framework was used for further analysis. We used the conceptual framework in this way because an a priori definition of analytical constructs is more likely to increase the quality of a case study than a free-form case study (Eisenhardt, 1991). In addition, an a priori framework provides a direction in exploring and illustrating research questions and is consistent with the tenets of case study research while at the same time allowing for emergent findings that invoke new concepts (Eisenhardt, 1991; Stoecker, 1991; Yin, 2003).

Initially, the data was structured to identify the various stages and phases of ecommerce adoption that the enterprise had passed through; then the data was analysed to identify which factors had influenced which particular parts of the adoption process. On this basis, a draft case report was prepared which was reviewed by both the participant author and the firm's owner-manager, allowing for greater confidence in the research results, including a check that factors absent in the initial data collection were not, in fact, influential (Stoecker, 1991). A further round of data interpretation then followed.

Overall, then, and consistent with our exploratory approach, we adopted an iterative process of data collection, analysis and checking that led to pattern identification and explanation building. We believe that the procedures followed in conducting the study and in triangulation of data collection methods contributed to the reliability and validity of the study (Stoecker, 1991; Yin, 2003). 


\section{CASE RESULTS AND ANALYSIS}

In this section, we first provide a contextual description of the case followed by detailed analysis.

\section{Case Background}

The case enterprise, Enòcoe (ancient Greek for a jar for wine), was located in the centre of Barcelona's 'Barri Gotic', the historical Roman/medieval city that is a principal tourist attraction. Enòcoe was established as a family business by the female owner in 2001 (see Table 1 for a summary profile). She had previously managed large medical and insurance enterprises for about a decade, and had then launched a microenterprise specialising in optical retailing which was abandoned after two years because of disagreement between its partners. Enòcoe was born out of the owner's desire to start a profitable business and provide a stable job for some members of her family. She chose a wine retail enterprise because she saw it as both a business opportunity and an opportunity to take advantage of her sister's competency as an oenology expert.

Enòcoe retailed quality wines and offered services such as oenology advice and courses, plus the organisation of wine-related conferences, exhibitions and even musical concerts. When asked what the enterprise's strategy was the owner responded, "we have to provide a selection of quality wine from around the world with affordable price. But at the same time, I want to attach Enòcoe's brand to every 
bottle of wine that we are selling so that our customers feel that they are buying more than a bottle of wine".

Table 1. Enòcoe's Profile

\begin{tabular}{|c|c|}
\hline Variable & Description \\
\hline Sector & $\begin{array}{l}\text { Wine retailing, combined with wine-related services such as } \\
\text { advice, training, and event organisation. }\end{array}$ \\
\hline $\begin{array}{l}\text { Survival } \\
\text { period }\end{array}$ & Two-and-a-half years (early-2001 to mid-2003). \\
\hline $\begin{array}{l}\text { No. of } \\
\text { employees }\end{array}$ & $\begin{array}{l}\text { Three full-time: the owner-manager, the operations manager (the } \\
\text { owner's sister), the shop manager (the owner's daughter); and } \\
\text { one part-time: the IT developer (the owner's son). A new } \\
\text { operations manager joined late in } 2002 \text {. }\end{array}$ \\
\hline $\begin{array}{l}\text { Owner- } \\
\text { manager } \\
\text { background }\end{array}$ & $\begin{array}{l}\text { The owner has a political science degree. Prior to starting } \\
\text { Enòcoe, she had more than twelve years' experience of } \\
\text { managing large and small enterprises. }\end{array}$ \\
\hline Customers & Residents of Catalonia and tourists visiting the region. \\
\hline Suppliers & $\begin{array}{l}\text { Wine was sourced from } 16 \text { Spanish, four French, one Italian, one } \\
\text { German and one South African supplier. Barcelona-based } \\
\text { suppliers provided accessory materials such as wine glasses and } \\
\text { other supplies necessary for running the business. }\end{array}$ \\
\hline Competitors & Main rivals were other small retail businesses located in the \\
\hline
\end{tabular}




\begin{tabular}{|c|c|c|c|}
\hline & $\begin{array}{l}\text { tourist centre o } \\
\text { large companies } \\
\text { that offered a fi } \\
\text { online services. }\end{array}$ & $\begin{array}{l}\text { na. Additi } \\
\text { ona such as } \\
\text { f wine and }\end{array}$ & $\begin{array}{l}\text { ompetitors included } \\
\text { te Inglés or Caprabo } \\
\text { elated products with }\end{array}$ \\
\hline Market scope & $\begin{array}{l}\text { Mainly the me } \\
\text { visiting (or inter }\end{array}$ & $\begin{array}{l}\text { area of } B \\
\text { sit or having }\end{array}$ & $\begin{array}{l}\text { a but also tourists } \\
\text { d) the region. }\end{array}$ \\
\hline $\begin{array}{l}\text { Competitive } \\
\text { strategy }\end{array}$ & $\begin{array}{l}\text { Not explicitly } \\
\text { high-quality, lo } \\
\text { products and bu }\end{array}$ & $\begin{array}{l}\text { vith the cor } \\
\text { nd value-ado } \\
\text { npany brand }\end{array}$ & $\begin{array}{l}\text { striving to provide } \\
\text { vice to differentiate }\end{array}$ \\
\hline $\begin{array}{l}\text { IT/IS } \\
\text { infrastructure }\end{array}$ & $\begin{array}{l}\text { Two personal } \\
\text { connection, two } \\
\text { shelf inventory } \\
\text { MS Access-bas } \\
\text { employees had }\end{array}$ & $\begin{array}{l}\text { rs, one lar } \\
\text { e lines and } \\
\text { ent system } \\
\text { er database } \\
\text { se competen }\end{array}$ & $\begin{array}{l}\text { an ADSL Internet } \\
\text { x line. An off-the- } \\
\text { in-house-developed } \\
\text { sement system. All }\end{array}$ \\
\hline \multirow[b]{2}{*}{ Profit (loss) } & 2001 (in $€$ ) & 2002 (in $€$ ) & $\begin{array}{l}\text { Year to July } 2003 \\
\text { (in } €)\end{array}$ \\
\hline & $-9,300$ & $-3,200$ & $-5,200$ \\
\hline
\end{tabular}

Enòcoe's base, Barcelona, is the capital of Catalonia in Spain. Catalonia is one of Spain's most affluent regions, and the comparative socio-economic context it provided for the enterprise is summarised in Table 2. 
Table 2. Comparative Socio-Economic Indicators for Catalonia

\begin{tabular}{|l|r|r|r|}
\hline \multicolumn{1}{|c|}{ Indicator } & Catalonia & Spain & EU-15 \\
\hline Population (2000) (in thousands) & 6,262 & 40,500 & 377,000 \\
\hline - Agriculture & 2.8 & 6.8 & 4.4 \\
- Industry and construction & 37.2 & 30.9 & 29.3 \\
- Services & 60.0 & 62.3 & 66.3 \\
\hline GDP per inhabitant (2000) (in $€$ ) & 18,807 & 15,031 & 21,828 \\
\hline Conventional telephone lines (2001) (per 100 inhabitants) & 49.3 & 43.1 & 40.6 \\
\hline Mobile telephone users (2001) (per 100 inhabitants) & 77.3 & 64.7 & 74.8 \\
\hline Households with computers (2001) (\%) & & & \\
\hline Households with Internet access (2001) (\%) & 27.1 & 23.4 & 35.0 \\
\hline
\end{tabular}

Source: Deiss (2002), Generalitat de Catalunya (2002a, 2002b)

Table 2 suggests a relatively favourable context for both Enòcoe and any e-commerce ambitions it had. Catalonia ranked above the Spanish average for both wealth and ICT infrastructure (a pattern repeated in transport infrastructure), and was even ahead of the EU average on some ICT measures. In spite of this, as shown in Table 3, Catalan businesses on average had made only limited progress along the stages of ecommerce capability: just over half had a Web site but these sites were largely restricted to an informational stage. Very few were engaged in transactional ecommerce, particularly with customers. 
Table 3. E-Commerce Status in Catalonia in 2001

\begin{tabular}{|l|r|}
\hline \multicolumn{1}{|c|}{ Indicator } & Percentage \\
\hline Businesses with a Web site & $57.8 \%$ \\
\hline Web capabilities: & $72.8 \%$ \\
- Information about products and services & $12.9 \%$ \\
- Interaction with customers & $8.2 \%$ \\
- Commercial transactions & $4.0 \%$ \\
- Integration with other systems & \\
\hline Percentage of businesses doing e-commerce: & \\
- B2C (business to consumer) & $6.4 \%$ \\
- B2B (business to business) & $27.3 \%$ \\
\hline
\end{tabular}

Source: Generalitat de Catalunya (2002b)

\section{History of E-Commerce Stages}

Drawing on the stage components of our conceptual framework (Figure 1), we can analyse Enòcoe's e-commerce history into four stages (see also Table 4 and Figure 2).

\section{Stage 1: Building a Web Presence (Feb-Nov 2001)}

In stage I, Enòcoe built a foundational e-commerce capability. 
From the firm's inception, the owner was thinking about how to use IT in general and the Internet in particular as a management and business tool, and she was convinced Enòcoe should have a Web presence. She and her son, the IT developer, held various meetings to discuss the best way to implement e-commerce but she stated, "I just thought that having a Web site would increase the visibility of my business. But in our deliberations, we never really looked at the experience of others. Nor did we seriously consider who is going to use the site".

Requirements were derived from Enòcoe's business model, such as it was, and comprised the design of a home page to publicise the firm, its products and services, and information about how to be a member of "Club Enòcoe". The IT developer contacted some local solution providers in Barcelona for quotations. But he also offered to build the site free of charge. He argued that developing the site in-house would bring various benefits: differentiating the Enòcoe site from standard sites developed by external firms, enabling site content to be more readily controlled, and enabling content to be updated easily and as frequently as desired.

The in-house option was selected and the first version of the site went live in November 2001. The IT developer reflected, "Ijust built the site using boxes. I didn't have previous experience so in a way I was learning while building it. Its appearance was really clumsy. There were no special features, no product catalogue to look at and not even a counter to monitor usage statistics". In addition, no action was taken to publicise the site and it was not registered with any search engines. 


\section{Stage II: Adding Search Capability (Dec 2001-Aug 2002)}

In stage II, a start was made on interactional capabilities by adding search facilities to the company Web site.

Although the owner-manager was unimpressed by the first version of Enòcoe's Web site, she took no action either to demand improvement or to outsource its further development. Earnings for the enterprise were below expectations (see Table 1) and its services section was not working well. The owner's primary concern was therefore to take measures that would strengthen Enòcoe's chance of making a profit. These measures did not involve using the Web, which no longer figured on her list of priorities. Despite these circumstances, the IT developer decided to improve the appearance and functionality of the Web. He reflected: "by then, I had heard about Flash 5.0, a Macromedia product to develop Websites with graphics and thought 'why not try it?'. For the functionality, I contacted SUMI [Enòcoe's local Internet service provider that hosted its Web site] to know the languages that their e-commerce server supports. My preference was to use Java but SUMI only supported ASP, SQL and Microsoft Access. I couldn't convince the owner to change server provider nor did I have the time or willingness to learn either ASP or SQL. So, instead I developed the second version entirely using Flash 5.0 without any product database. This was indeed a wrong decision and made updating the product catalogue a very painful and tedious manual process."

The updated version of Enòcoe's Web site went live in March 2002. Most of its contents, which were created by the shop manager and approved by the owner were updated frequently. Its visibility was considered by registering it with Google, Yahoo 
and Terra search engines. But no other action was taken to publicise it either within the shop or elsewhere. Further, no-one monitored site usage nor did they evaluate what impact, if any, the Web had on the business.

Stage III: Planning Transactional E-Commerce (Sep 2002-May 2003)

The arrival of a new operations manager in September 2002 initiated the third stage of Enòcoe's e-commerce trajectory, in which a plan was made to upgrade to transactional capability.

The new operations manager saw e-commerce as a means to improve the organisation's unsatisfactory bottom line. Thus he proposed a fully-fledged ecommerce application, capable of handling online orders and payments; an idea the owner supported. The IT developer was given the task of application upgrade. However, the enterprise could provide no additional budget for him, and he had neither the skills nor the time to develop the required system. Implementation therefore stalled, particularly as alternative development routes - such as use of external solutions providers - were not considered feasible.

\section{Stage IV: E-Commerce and Enterprise Failure (Jun-Jul 2003)}

In the final stage, lack of progress on transactional e-commerce was recognised and the project was formally abandoned in June 2003. Enòcoe's financial situation worsened, and it finally went out of business in July 2003. The immediate reason for business closure was cashflow problems which, in turn, related to the inability of the business to attract enough customers to generate sales sufficient to meet its expenditure. 
Table 4. Key Features of the Four Phases of E-Commerce Adoption at Enòcoe

\begin{tabular}{|c|c|c|c|c|}
\hline \multirow[t]{2}{*}{ Stage } & \multirow{2}{*}{$\begin{array}{l}\text { Intended } \\
\text { Commerce } \\
\text { Capability }\end{array}$} & \multicolumn{3}{|c|}{ E-Commerce Adoption Process Phases } \\
\hline & & Initiation & Decision & Implementation \\
\hline $\begin{array}{l}\text { I (Feb- } \\
\text { Nov } \\
\text { 2001) }\end{array}$ & $\begin{array}{l}\text { Web Presence } \\
\text { (Informational) }\end{array}$ & $\begin{array}{l}\text { The owner, based on her previous } \\
\text { experience with IT and Internet systems, } \\
\text { raised the idea of having a Web site with } \\
\text { her son, the IT developer. The objective } \\
\text { was to use the Web as a marketing tool. } \\
\text { The prospect of increased revenue } \\
\text { through e-commerce was particularly } \\
\text { attractive to the owner. }\end{array}$ & $\begin{array}{l}\text { The IT developer wanted to use the opportunity to } \\
\text { develop his own Web development skill and the cost } \\
\text { of other solution providers was expensive. Hence, the } \\
\text { developer, though lacking in skills, convinced the } \\
\text { owner to let him develop the Web site. She produced } \\
\text { the initial requirement list for the site, selected SUMI } \\
\text { (a local ISP) as a server provider based on her previous } \\
\text { experience, and allocated a total budget of } € 1,130 \text {. } \\
\text { Delivery date was set for August } 2001 \text {. The developer } \\
\text { selected Catalan as the site language, and decided to } \\
\text { build it using HTML. }\end{array}$ & $\begin{array}{l}\text { 1GB of server space was allocated as the standard } \\
\text { package from SUMI. A domain name (www.vinoteca- } \\
\text { enocoe.com) was registered. The operations manager } \\
\text { provided the content and the first version of the Web site } \\
\text { went live in Nov. 2001. Implementation was lengthy due } \\
\text { to (1) the IT developer's lack of skill, (2) his other } \\
\text { commitments, and (3) an unhealthy working relationship } \\
\text { between himself and the operations manager. Web site } \\
\text { content included company mission, objectives, location, } \\
\text { and service statements with a direct e-mail link. }\end{array}$ \\
\hline $\begin{array}{l}\text { II (Dec } \\
2001 \quad- \\
\text { Aug } \\
2002)\end{array}$ & $\begin{array}{l}\text { Search } \\
\text { Capability } \\
\text { (Interactional) }\end{array}$ & $\begin{array}{l}\text { The owner's priority was addressing } \\
\text { enterprise losses, and she did not perceive } \\
\text { a role for further e-commerce } \\
\text { developments. Change was therefore } \\
\text { driven by the IT developer's desire to } \\
\text { improve Web functionality for customers. }\end{array}$ & $\begin{array}{l}\text { The IT developer's enthusiasm drove the decision- } \\
\text { making process, within constraints set by a lack of } \\
\text { budget, and by a lack of compatibility between his } \\
\text { technical preferences and the software supported by } \\
\text { the firm's ISP. The technology chosen did not support } \\
\text { database manipulation, and no delivery time was set } \\
\text { for the interactional capability. }\end{array}$ & $\begin{array}{l}\text { The implementation process was shorter than for the } \\
\text { establishment of a Web presence. The shop manager used } \\
\text { Excel to prepare Enòcoe's product catalogue, which could } \\
\text { not be uploaded directly to the Web. Other informational } \\
\text { content was frequently updated but the time-consuming } \\
\text { process of making the catalogue available on the Web } \\
\text { meant it was only updated once during this period. }\end{array}$ \\
\hline
\end{tabular}




\begin{tabular}{|c|c|c|c|c|}
\hline $\begin{array}{l}\text { III (Sep } \\
2002- \\
\text { May }\end{array}$ & $\begin{array}{l}\text { Online Trading } \\
\text { (Transactional) }\end{array}$ & $\begin{array}{l}\text { The new operations manager believed } \\
\text { that e-commerce could help achieve his } \\
\text { primary goal of delivering enterprise } \\
\text { profitability. Both owner and IT } \\
\text { developer supported his idea to further } \\
\text { develop the firm's e-commerce capability. }\end{array}$ & $\begin{array}{l}\text { The operations manager made the framework decision } \\
\text { to build an e-commerce system integrated with the } \\
\text { inventory management and customer database } \\
\text { systems, that would handle online orders and } \\
\text { payments. Within this general framework, the IT } \\
\text { developer was again left to make design decisions. } \\
\text { The decisions were again constrained by no additional } \\
\text { budget, and by the support of only ASP and SQL - in } \\
\text { neither of which the IT developer possessed skills - by } \\
\text { the ISP hosting the firm's Web presence. }\end{array}$ & $\begin{array}{l}\text { Implementation was troubled as the developer was } \\
\text { abroad. He did not have the required competencies to } \\
\text { build the planned e-commerce systems, and he was } \\
\text { concerned about the legal and security implications of the } \\
\text { step up to transactionality. No link was ever established } \\
\text { with service fulfilment providers (such as delivery and } \\
\text { credit card processing companies), although the IT } \\
\text { developer did begin development of an SQL+ASP } \\
\text { application towards the end of this stage. }\end{array}$ \\
\hline $\begin{array}{l}\text { IV (Jun- } \\
\text { Jul } \\
\text { 2003) }\end{array}$ & None & $\begin{array}{l}\text { Enterprise financial losses continued and } \\
\text { cash flow problems accumulated. Given } \\
\text { that no business benefit from e-commerce } \\
\text { could be seen, the owner initiated a final } \\
\text { stage. }\end{array}$ & $\begin{array}{l}\text { The owner decided that the e-commerce project should } \\
\text { be abandoned and, shortly after, decided to close the } \\
\text { retail business. }\end{array}$ & $\begin{array}{l}\text { The stage III project was abandoned in June } 2003 \text {. } \\
\text { Server rent was cancelled and the firm's Web site finally } \\
\text { went down in July } 2003 \text {. }\end{array}$ \\
\hline
\end{tabular}




\section{Analysis of the Factors Affecting E-Commerce Adoption}

The chronology presented can now be analysed further in terms of the factors and adoption phases identified in the conceptual model. The results of initial analysis are presented in Table 4, with further consideration against the COME category factors provided in the text below.

\section{Contextual factors}

Typical external forces did not drive the initiation of e-commerce at Enòcoe, nor significantly shape its decision and implementation phases. Enòcoe's clients never expressed the need for an online service. Its suppliers - despite being based in countries with above-average e-readiness rankings (Dutta et al., 2003) - exerted no pressure. None of Enòcoe's main rivals had a strong Web presence that might impel plans for e-commerce, and e-commerce uptake in the local business community was relatively limited (see Table 3). In a general sense Catalonia's well-developed telecommunications infrastructure influenced e-commerce initiation and decisionmaking but not always in a positive way. It may have contributed to a misreading of the market, with good infrastructure encouraging adoption even though few Catalans were using the Internet to buy online.

Of more significant effect on adoption were local e-commerce-related organisations. Local e-commerce solution providers offered a standard and relatively high cost service (development, maintenance and update) that matched neither Enòcoe management's expectations nor its budget. In particular, commercial e-commerce developers offered standard design templates with an interface too rigid to be 
customised to meet Enòcoe's needs. This impelled the decision to develop the ecommerce function in-house. In the same vein, the IT infrastructure of SUMI, the server host, influenced the technical decisions (such as programming language) made at Enòcoe, adding to the complexity of the project and affecting its quality and timely delivery.

Other contextual issues, such as unclear laws governing electronic transactions, and security considerations were seen to have made some contribution to delays in implementation of the first and, particularly, third e-commerce stages.

\section{Organisational factors}

Two factors stand out among the organisational factors affecting Enòcoe's ecommerce trajectory: people and money. The presence of an in-house IT developer interested in developing a commercial Web site significantly shaped Enòcoe's ecommerce agenda from start to finish. For example his individual competencies played an important role in shaping technical decisions as well as the speed and direction of their implementation.

People, though, are not merely resources and "softer" human factors influenced adoption. The developer saw the development of the e-commerce function in Enòcoe as an opportunity to develop his own skills and career potential; leading personal objectives to shape technology adoption, particularly initiation and decision-making. Beneath our language such as "owner" and "IT developer", it must also be remembered that this was a family business of mother, son, sister and aunt. Informality and simplicity - characteristics of microenterprises and family-run 
businesses - will have helped speed Enòcoe's e-commerce decisions (Daniel \& Grimshaw, 2002), yet they do not necessarily optimise those decisions. Informal relations affected most adoption decisions with, for example, greater latitude allowed to the "IT developer" than might have been the case had a more objective decisionmaking process been used. Likewise, poor relations between IT developer and operations manager delayed first stage implementation.

This informality may also run alongside a conservatism, with a reluctance to disturb the status quo of relations and responsibilities that have a high social content. For instance, the owner wished to retain overall control of inventory despite allowing the electronic inventory file to be administered by her daughter, the shop manager. The result, during implementation of the third stage, was a requirement for a new interface to report all inventory changes to the owner.

Enòcoe's financial resources were significant in two ways. First, because Enòcoe's earnings were far below expectation, e-commerce see-sawed between being pushed aside as irrelevant to being seen as the magic bullet to save the firm. Second, the limited financial resources of Enòcoe affected the budget allocated to e-commerce which, in turn, impacted decisions about functionality, server provider, developer, etc.

\section{Managerial factors}

Of importance to e-commerce initiation in Enòcoe were its owner's competencies visà-vis IT-based systems: her past experience, her hands-on skills, and her positive attitude. Particularly, her knowledge and familiarity with the Internet and her belief 
in its potential benefits played a crucial role in starting Enòcoe's e-commerce agenda and in approving the plan to build full e-commerce capability in the third stage.

The owner's influence on the decision-making phase varied, itself shaped by factors such as the gap between expected and actual benefits that e-commerce delivered in its implemented stages; her informal relation with her son, the IT developer; and the perceived solutions to Enòcoe's financial difficulties. The overall sense is that this influence was driven more by intuition than rationality, paying little attention to strategic contextual imperatives based on market evidence, and paying more attention to family interests. That influence was also erratic: strong when taking major decisions like the initial in-house path or e-commerce abandonment, but weak in other stages and largely absent in relation to technical decisions or to the implementation phase.

\section{E-commerce-specific factors}

As noted above, it is the perceptions of e-commerce rather than objective measures that are seen to impact adoption (Riemenschneider \& McKinney, 2001; Grandon \& Pearson, 2003). In this case, the perceived benefits of e-commerce - low cost visibility for the firm, potential increase in sales - were instrumental in convincing the owner, IT developer and operations manager to initiate two phases of adoption. Conversely, when the expected benefits failed to materialise, this led to withdrawal of support and abandonment of e-commerce.

The trialability attribute of e-commerce contributed to the IT developer's decision to offer his service. He knew, even if he initially lacked the skills and experience to 
develop the system, he could build these up through experimentation. Trialability thus also informed the owner's decision not to outsource the development to professional solution providers. Combined with the complexity of higher-level ecommerce, this shaped Enòcoe's whole approach to e-commerce by pushing them towards an incremental approach. Indeed, it was complexity that encouraged Enòcoe to take only limited incremental steps in the first two stages, and it was the need to make a significant step-change in complexity for the third stage that helped delay and then, ultimately, undermine implementation.

Figure 2 presents an overview of these key factors affecting e-commerce adoption in Enòcoe. There is no clear pattern of different factors impacting the three different adoption stages but we can summarise the main factors that affected Enòcoe's different e-commerce phases, as shown in Table 5. 
Table 5. Key Factors Affecting Different E-Commerce Adoption Phases at

Enòcoe

\begin{tabular}{|c|c|c|c|}
\hline \multirow{3}{*}{$\begin{array}{l}\text { Category } \\
\text { Contextual }\end{array}$} & \multicolumn{3}{|c|}{ Adoption Phase } \\
\hline & Initiation & Decision & Implementation \\
\hline & & $\begin{array}{l}\text { Solution provider cost } \\
\text { and rigidity } \\
\text { ISP's IT infrastructure }\end{array}$ & $\begin{array}{l}\cdot \text { ISP's } \\
\text { infrastructure } \\
\text { Telecom, legal } \\
\text { infrastructure }\end{array}$ \\
\hline Organisational & $\begin{array}{l}\text { IT developer's } \\
\text { personal objectives } \\
\text { and knowledge } \\
\text { Financial constraints }\end{array}$ & $\begin{array}{l}\cdot \text { IT developer's } \\
\text { personal objectives } \\
\text { - Financial constraints } \\
\text { - Informal relations }\end{array}$ & $\begin{array}{l}\text { - IT developer's skill } \\
\text { - Informal relations }\end{array}$ \\
\hline Managerial & $\begin{array}{l}\text { Owner attitude } \\
\text { Owner knowledge }\end{array}$ & - Owner intuition & \\
\hline $\begin{array}{l}\text { E-commerce- } \\
\text { specific }\end{array}$ & Relative advantage & $\begin{array}{l}\text { Complexity } \\
\text { Trialability }\end{array}$ & Complexity \\
\hline
\end{tabular}


Figure 2. Factors, Stages and Phases in Enòcoe's E-Commerce History

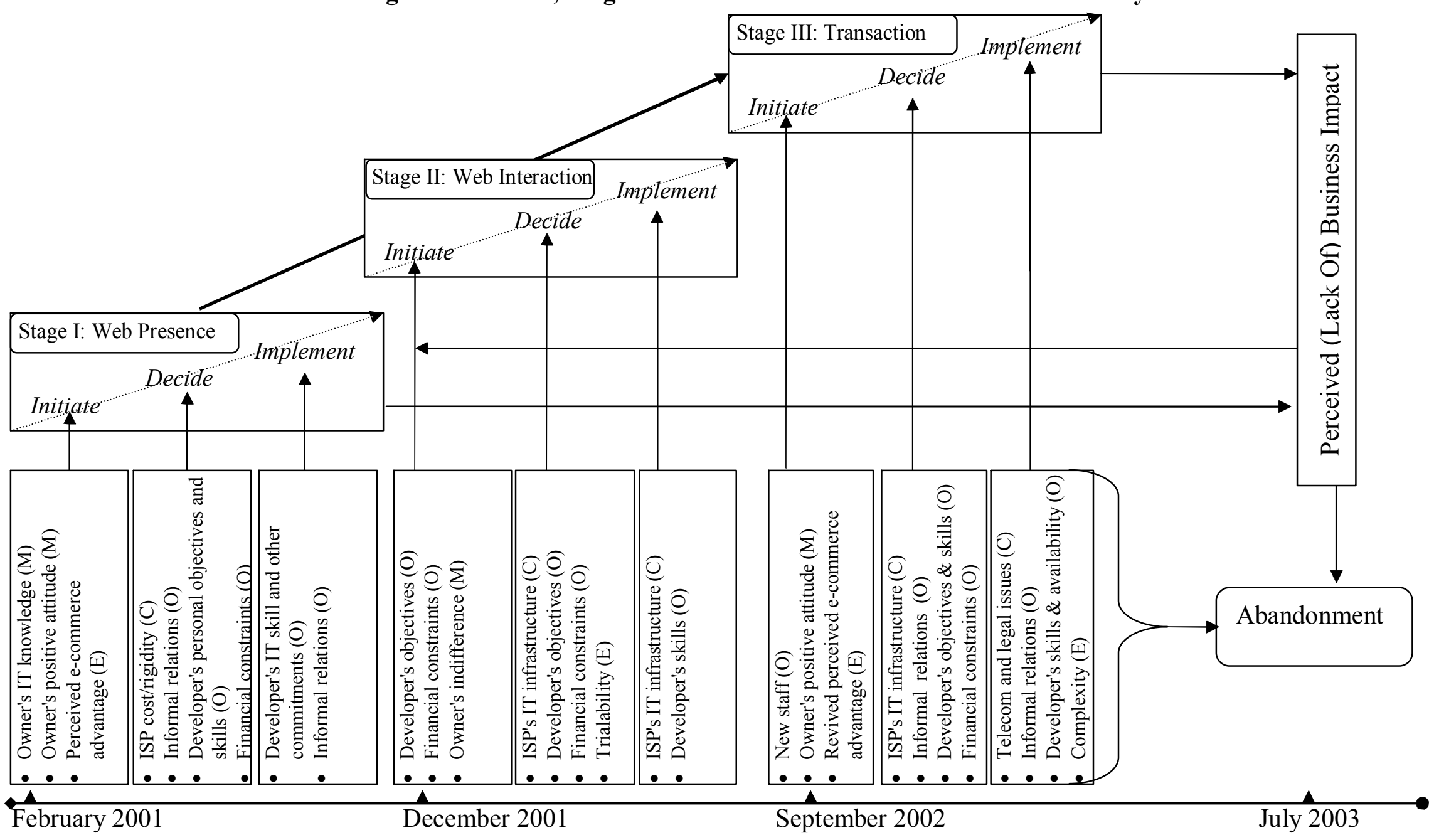




\section{DISCUSSION}

Within the bounds of the methodological limitations of the study, a few theoretical and practical implications can now be outlined.

\section{Theoretical Implications}

\section{COME Factor Categorisation}

Our classification of past research suggested that the technology-organisationenvironment framework (Tornatzky and Fleischer, 1990) can be expanded to include managerial factors and the factors affecting e-commerce adoption could be arranged into four categories: contextual, organisational, managerial, and e-commerce-specific. In an overall sense, this categorisation within our conceptual framework has proven workable and useful in analysing the e-commerce experiences of an individual enterprise.

We noted that the factors reviewed should be seen more as characteristic factors identified by a number of studies rather than as an exhaustive list of all possible factors. Within this constraint, we can reflect on the factors that did and did not emerge from this case, summarised in Table 6. 
Table 6. Comparing Case E-Commerce Drivers/Inhibitors to Characteristic Factors from Earlier Literature

\begin{tabular}{|c|c|c|c|}
\hline \multirow[t]{2}{*}{ Category } & \multirow{2}{*}{$\begin{array}{l}\text { Characteristic } \\
\text { Factors from } \\
\text { Literature }\end{array}$} & \multicolumn{2}{|c|}{ Case Study Findings } \\
\hline & & $\begin{array}{l}\text { Factors with positive } \\
\text { influence (e- } \\
\text { commerce drivers) }\end{array}$ & $\begin{array}{l}\text { Factors with negative } \\
\text { influence (e-commerce } \\
\text { inhibitors) }\end{array}$ \\
\hline Contextual & $\begin{array}{l}\text { Sector } \\
\text { Customers } \\
\text { Competitors } \\
\text { Suppliers } \\
\text { Location }\end{array}$ & $\begin{array}{l}\text { Possible influence of } \\
\text { strong } \\
\text { telecommunications } \\
\text { infrastructure }\end{array}$ & $\begin{array}{l}\text { ISP infrastructure and } \\
\text { cost/rigidity }\end{array}$ \\
\hline Organisational & $\begin{array}{l}\text { Structure } \\
\text { Process } \\
\text { Resources }\end{array}$ & $\begin{array}{l}\text { Developer's personal } \\
\text { objectives } \\
\text { Staff enthusiasm } \\
\text { Informal relations }\end{array}$ & $\begin{array}{l}\text { Developer's personal } \\
\text { objectives, skills and } \\
\text { availability } \\
\text { Financial constraints } \\
\text { - Informal business } \\
\text { processes and relations }\end{array}$ \\
\hline Managerial & $\begin{array}{l}\text { Owner attitudes } \\
\text { Owner skills }\end{array}$ & $\begin{array}{l}\text { Owner's IT knowledge } \\
\text { Owner's enthusiasm } \\
\text { Owner's support }\end{array}$ & $\begin{array}{l}\text { Owner's indifference } \\
\text { Owner's lack of strategic } \\
\text { approach }\end{array}$ \\
\hline E-Commerce & $\begin{array}{l}\text { Technical } \\
\text { characteristics } \\
\text { Relative advantage } \\
\text { Compatibility } \\
\text { Trialability }\end{array}$ & $\begin{array}{l}\text { Relative advantage to } \\
\text { attain visibility and } \\
\text { increase sales } \\
\text { Trialability }\end{array}$ & $\begin{array}{l}\text { Perceptions of lack of } \\
\text { advantage gained } \\
\text { Complexity }\end{array}$ \\
\hline
\end{tabular}


Some factors found here correspond to those found in earlier studies. The Enòcoe case, for example, confirms previous studies' findings (Harrison et al., 1997; Grandon \& Pearson, 2003) that the enterprise owner's attitude and other competencies play a key role in affecting e-commerce adoption. Issues of staff competencies, financial resources and all e-commerce-specific factors have also been reported elsewhere (e.g. Riemenschneider \& McKinney, 2001; Seyal \& Rahman, 2003).

In other ways, though, this case does not quite match earlier work. Previous writings have tended to equate contextual drivers affecting small firms' e-commerce adoption either simply with competition (Lertwongsatien \& Wongpinunwatana, 2003) or with pressure from customers and suppliers as well as competitors (Keeling et al., 2000; Daniel \& Grimshaw, 2002; Loforte \& Love, 2003). Here, though, there was an absence of this type of external contextual influence. This could relate to the sector or region, with their relative conservatism vis-à-vis e-commerce transactions; to the very small size of the enterprise, making it less of a target for supplier or consumer pressure; or to the related informality of decision-making and transactions so that, for example, e-commerce decisions had a tendency to focus more on intuition and family interests than a rational scan of contextual pressures.

Where decisions were influenced by context, this came mainly in the very immediate shape of the technical constraints imposed by choice of ISP. While not reflected in the majority of earlier work on e-commerce and small enterprise, this is resonant with ideas about the importance of external intermediaries or change agents (Brown \& Lockett, 2001; Elsammani et al., 2004). 
Another factor found here that is not particularly well-represented in earlier research is the importance of informal, social processes and relations. We have seen this to affect most phases and most stages of e-commerce adoption. It even impacted the precise timing of enterprise abandonment, with the retail outlet being closed just prior to the family's annual holiday.

In part, the differences between these results and those of previous studies may be explained by the small size and fragility of this enterprise: a typology that, as noted, is archetypical of enterprise. Even setting this aside, though, the results here are also a reminder that the factors which affect e-commerce adoption in any individual enterprise are by no means bound to match the "averages" - such as the contextual factors noted above - portrayed by survey research; a reminder useful for both researchers and practitioners.

\section{Incorporating Adoption Phases}

As noted in developing our conceptual framework, most previous studies have tended to focus on a simple dichotomy between adoption and non-adoption. Enòcoe's case has supported the idea that adoption is more complex than this and should not be black-boxed. Given the incremental nature of e-commerce, adoption is reflected in a set of stages that seek to adopt increasingly complex e-commerce applications. Each adoption process itself can be understood as phases of initiation then decision then implementation. From this latter perspective, we see that factoral influence is not uniform: different factors impact different phases of the adoption process. Thus, for example, contextual factors were not found to affect the initiation of e-commerce while, by contrast, managerial factors had little impact on its implementation. 
Likewise, it was the relative benefits of e-commerce that shaped its initiation but its complexity and trialability that shaped subsequent phases of adoption. Our research therefore helps, as intended, to move beyond the correlational findings of previous work to illustrate how and when particular factors impact the e-commerce adoption process. Further work will, of course, be needed to draw out more consistent patterns within the different phases of adoption; patterns that this single case study cannot yet generalise to identify.

\section{Questioning E-Commerce Model Assumptions}

Despite incorporation of both stage and phase chronologies into the conceptual framework explored here, and despite support for those chronologies from this case, Enòcoe's experience does question the optimistic, progressive assumptions built into most standard stage and phase models. The stage model assumes an ever-building ecommerce functionality; the phase model assumes that implementation leads to beneficial use of innovations like e-commerce. At first, Enòcoe replicated these assumptions. Eventually, though, it did not.

This enterprise moved from an informational stage to an interactional stage of ecommerce but then to abandonment rather than to a transactional stage. Its final adoption phases therefore moved from initiation to decision to implementation but then not, as innovation theory assumes, to assimilation. Instead, again, it moved to abandonment. During this phase specific factors were at play: not just the financial problems that impacted other adoption phases but also specific issues of the owner's loss of faith in e-commerce due to its failure to deliver on earlier-perceived benefits. 
As already pointed out, this is just a single case study but its abandonment of ecommerce does fit with the broader findings on IS failure noted earlier. The progressive assumptions of e-commerce and innovation models are, therefore, not always mirrored in reality: adoption trajectories may equally be regressive; something that researchers must learn to accommodate. As shown here, that accommodation can include use of extended models of adoption to understand rejection. The conceptual framework presented is one such model; extended to explicitly incorporate abandonment and thus applicable to e-commerce failures as well as successes.

\section{The Value of Chronological Case Studies}

The use of explicitly chronological case study approach has been substantiated. Use of a case study has allowed a depth of description, analysis and understanding of ecommerce that would not otherwise be possible. The case has also exposed the importance of history in e-commerce adoption, contrasting with the way in which most work to date - based on simple factor models and survey research - is implicitly cross-sectional and fails to reflect the impact that earlier stages and phases are found to have on later ones. At a simple level, the historical imperative can be seen in the way that the failure of earlier stages of e-commerce to deliver benefits supported later abandonment. More intricately, we can see the way in which early decisions such as in-house development or choice of ISP echoed throughout later stages of e-commerce adoption.

As an emergent finding from the case, then, we see a need for research on ecommerce to grasp the concept of "path dependency": the generic formulation for understanding the way in which earlier events and decisions affect subsequent events 
and decisions (e.g. David, 1985; Greener, 2002). If our own and other studies question the simple progressive path suggested by "stages of growth" models (e.g. Levy \& Powell, 2003), then we must look to alternative conceptualisations such as path dependency to understand the e-commerce paths that enterprises really do take.

\section{Practical Implications}

In some ways, this case study reinforces the messages of earlier work, such as the importance of the individual in small firm e-commerce adoption, particularly the owner (Thong, 1999). This case was different, though, in that adoption of ecommerce did not underpin small enterprise success; in fact, e-commerce cannot be seen to have delivered any tangible benefits. One can interpret this outcome in at least two ways.

On the one hand, one might argue that it was the particular approach to e-commerce that was at fault. Had the enterprise outsourced Web development, or had it given adequate budgetary provision to e-commerce then perhaps benefits would have emerged. Yet it is hard to see real alternative choices that could have been made in practice and this prompts a different possible interpretation of the case: that ecommerce was at best a distraction for this small enterprise and at worst a diversion of critical resources.

The evidence base from one enterprise is limited but it may give pause for thought about the generalised assumption underlying writings about e-commerce and small enterprise: that e-commerce is a "good thing". This assumption has, for instance, led to only one practical conclusion in the literature about small enterprises without e- 
commerce: that one must identify the constraints to e-commerce that exist in such non-adopters and then address those constraints in order to push those firms along the e-commerce road. This case suggests - though by no means proves - a possible alternative: that, for some small enterprises, non-adoption might be a rational choice because e-commerce will not be sufficiently beneficial to justify adoption (and might even be strategically damaging for very resource-poor, competitively-challenged microenterprises like the one reviewed here).

By illustrating the importance of a historical perspective and the potential for path dependency, this case has also shown that e-commerce decisions and actions have longer-term as well as shorter-term effects. This may be particularly significant in small firms given the nature of decision-making in such firms: decision-making (as reflected both in this case and broader literature (Levy \& Powell, 2000; Daniel \& Grimshaw, 2002)) that is lacking in strategic or long-term focus, and which tends to be based on intuition and subjective/informal factors rather than on formal, rational analysis. The result is that e-commerce decisions are being taken on a personalised basis - often to try to quickly solve a perceived problem or need - that have unforeseen and possibly disadvantageous impacts on the enterprise in the longer-term by reducing flexibility and benefits or by imposing higher costs. Hence, for example, apparently low-cost solutions - in-house development, or taking advantage of "free" products/services - may turn out, in the longer-term, to be high-cost solutions. In this case, the lower-cost route of using a family member as e-commerce developer can fairly directly be linked to lack of benefit delivery in later stages. 
A fairly-obvious practical recommendation is that entrepreneurs should factor in the longer-term implications of their e-commerce decisions. One must, though, recognise the limitations of such exhortations, like those made by other writers such as advice to small entrepreneurs to outsource their e-commerce applications (Daniel \& Myers, 2000), or to evaluate their e-commerce applications by benchmarking (Chen et al., 2003). These recommendations draw from foundations of formal objectivity yet informality and subjectivity are, instead, endemic to small enterprises and one cannot just wish them away. This limits the viability of other possible recommendations, such as the value of aligning e-commerce strategy with business strategy: something that might have identified for Enòcoe the disjuncture between their targeting of the tourist market and the use of Catalan as the sole language for their Web site.

A more feasible approach may be to focus on change agents; those private and public organisations that act to support e-commerce in small enterprise (Elsammani et al., 2004). We have seen in Enòcoe's case how one such organisation's costing and technical decisions affected technology adoption. In planning their own activities, support organisations therefore need to understand what an important influence they have. This understanding can be developed through the conceptual model validated here: acknowledging that different factors over which the support organisations have control have effects during different phases of adoption; and that effects in early stages impact later stages.

The responsibilities of some support organisations - like the case study ISP - will be limited. For those with more collective responsibilities such as government agencies, though, practical work is likely to include awareness-raising; for example, as per 
findings above, making entrepreneurs aware that short-term quick fixes may bring longer-term problems; making entrepreneurs aware of actual rather than hypothetical e-commerce benefits (thus helping make expectations more realistic); and more generally building and disseminating repositories of good and bad practice. Use of the model described here to analyse local populations will also provide guidance on issues such as the relative balance of support to give to in-house vs. outsourced ecommerce provision

\section{Limitations}

This paper reports an individual case study used in an exploratory, illustrative approach to a synthesised conceptual model. It therefore cannot be used in the same way for generalisation as a hypothesis-testing, survey-based piece of research could. All we can claim here is that a chronological framework can be applied to ecommerce adoption, and that different factors do sometimes impact different adoption phases. It will need further research to draw out more general patterns of relation between particular factors and particular phases.

We collected data based mainly on interview and document analysis plus post hoc accounts of participation. These methods are susceptible to retrospective bias and errors, although we believe that the precautions we took help protect against such errors (Golden, 1992). However, given the centrality of chronology, a more truly longitudinal research design would be valuable for future case-based work.

Finally, we selected a particular type of case: a microenterprise that failed after a few years. These enterprises may have characteristics that should be balanced by 
investigation of larger and more successful enterprises. Having said this, such latter enterprises have been too dominant in past research and we believe that small enterprise research - indeed, enterprise research generally - should do much more to incorporate cases like Enòcoe because these represent by far the most widespread form of enterprise.

Alongside the archetypical value of such cases, though, we must also recognise the additional challenges they raise, especially around the issue of failure and particularly where - as in this case - there is the double failure of both e-commerce as well as enterprise. This is not an issue we have explored in great detail, in part because of the apparent relative lack of relation between these two failures. We have only noted that cashflow and sales issues - not e-commerce failure - were the cause of enterprise failure. Yet there may be a deeper story. We have argued the potentially problematic diversion of resources into e-commerce, and can also point out that, while ecommerce failure might not have caused enterprise failure, e-commerce success would likely have postponed or even averted enterprise failure. In addition, enterprise failure postdated e-commerce failure, so was not a direct cause but at the least the financial constraints imposed by a failing enterprise did affect the trajectory of ecommerce. Given that enterprise failure is so common, there is clearly a rich vein of further research that would seek to understand the two-way relation between ecommerce and enterprise failure. 


\section{CONCLUSION}

Small enterprises constitute a crucial engine for economic growth. Developing their efficiency, effectiveness and competitiveness has significant social and economic implications. E-commerce presents an opportunity for enhancing such capacities, which we have studied here through the case of a retail microenterprise that ultimately failed.

The key contributions we believe that emerge from this paper are three-fold, related to adoption factors, adoption process, and chronological case approach. First, we have confirmed the value of understanding e-commerce adoption in small enterprise through a four-way categorisation encompassing contextual, organisational, managerial, and e-commerce-specific factors. Comparisons with previous work are tempered by recognition of the limitations of generalisation from a single case but we found, for example, a lack of impact from contextual factors such as competition or customers and, instead, a strong influence of informal, social processes and relations, and a potentially-important role for external support organisations.

Second, we highlighted the way in which adoption of e-commerce involves phases of initiation, decision and implementation. This expands beyond the simple adoption/non-adoption dichotomy of earlier work, and enables us to understand how different factors affect different phases of e-commerce adoption; something that both entrepreneurs and their support organisations need to understand. 
Finally, our chronological and case study approach has allowed a rich historical insight into the process of e-commerce adoption, and this is an approach that we would commend to other e-commerce researchers. Both practitioners and researchers must understand the dependencies that a chronological perspective exposes. We found that small enterprise decision-making may be characterised by short-termism and subjectivity but such characteristics can set firms on a path which later, while hard to escape, significantly constrains the ability of e-commerce to deliver business benefits.

From this we see, at least in this case, that we cannot assume adoption to always be a linear, progressive process. Sometimes it is unclear - despite growing functionality that e-commerce is truly adding value to the enterprise; and sometimes adoption ends with abandonment. Uncritical promotion of e-commerce stages for small enterprise must therefore be replaced by an approach attuned more to the realities of those enterprises. 


\section{REFERENCES}

ALEXANDER A (1999) Tuning small business for e-commerce. Accounting Technology 15(11), 48-54.

AU YA and KAUFMAN RJ (2001) Should we wait? Network externalities, compatibility and electronic billing adoption. Journal of Management Information Systems 18(2), 47-75.

AUGER P and GALLAUGHER JM (1997) Factors affecting the adoption of an Internet-based sales presence for small business. Information Society 13(1), 55-74.

BALDWIN A, LYMER A and JOHNSON R (2001) Business impacts of the Internet for small and medium-sized enterprises. In E-commerce and V-Business: Business Models for Global Success (Barnes S and Hunt B, Eds), pp 103-120, ButterworthHeinemann, Oxford.

BENBASAT I, GOLDSTEIN DK and MEAD M (1987) The case research strategy in studies of information systems. MIS Quarterly 11(3), 369-386.

BEVEREN JV and THOMSON H (2002) The use of electronic commerce by SMEs in Victoria, Australia. Journal of Small Business Management 40(3), 250-253.

BROWN DH and LOCKETT NJ (2001) Engaging SMEs in e-commerce: the role of intermediaries within e-clusters. Electronic Markets 11(1), 52-58.

CHEN L, HANEY S, PANDZIK A, SPIGARELLI J and JESSEMAN C (2003) Small business Internet commerce: a case study. Information Resources Management Journal 16(3), 17-42.

CHETTY S (1996) The case study method for research in small and medium-sized enterprises. International Small Business Journal 15(1), 73-86.

CLOETE E, COURTNEY S and FINTZ J (2002) Small businesses' acceptance and adoption of e-commerce in the Western-Cape province of South Africa. The Electronic Journal on Information Systems in Developing Countries 10(4), 1-13.

DANIEL EM and GRIMSHAW DJ (2002) An exploratory comparison of electronic commerce adoption in large and small enterprises. Journal of Information Technology 17(3), 133-147.

DANIEL EM and MYERS A (2000) Levelling the Playing Field: Electronic Commerce in Small and Medium Enterprises, School of Management, Cranfield University, Cranfield, UK. http://www.som.cranfield.ac.uk/som [accessed June 2005] 
DANIEL EM, MYERS A and WILSON H (2002) Adoption of e-commerce by SMEs in the UK. International Small Business Journal 20(3), 253-270.

DAVID PA (1985) Clio and the economics of QWERTY. The American Economic Review 75(2), 332-337.

DEISS R (2002) E-commerce in Europe. Statistics in Focus Theme 4, 12/2002, 1-7.

DIRECCIÓN GENERAL DE POLÍTICA DE LA PYME (2002) Las PYME en España 1996/2000. Secretaría de Estado de Economía, de la Energía y de la Pyme, Ministerio de Economía, Madrid. http://www.ipyme.org/dgpyme/manuales/pyme_96_00.pdf [accessed June 2004]

DUTTA S and EVRARD P (1999) Information technology and organisation within European small enterprises. European Management Journal 17(3), 239-251.

DUTTA S, LANVIN B and PAUA F (Eds) (2003) The Global Information Technology Report 2002-2003: Readiness for the Networked World. World Economic Forum, Geneva.

EC (2003) 2003 Observatory of European SMEs, no.8. European Commission, Brussels. http://europa.eu.int/comm/enterprise [accessed June 2005]

EDUARD T (2002) Adding Clicks to Bricks. Consulting to Management C2M 12(4), $10-23$.

EISENHARDT KM (1991) Better stories and better constructs: the case for rigor and comparative logic. Academy of Management Review 16(3), 620-628.

ELSAMMANI Z, HACKNEY R and SCOWN P (2004) SMEs adoption and implementation process of Websites in the presence of change agents. In Electronic Commerce in Small to Medium-Sized Enterprises: Frameworks, Issues, and Implications (Al-Qirim NAY, Ed), pp 146-163, Idea Group Publishing, Hershey, PA.

ELSAMMANI Z and SCOWN P (2000) How SMEs perceive and develop their Web presence. Journal of New Product Development and Innovation Management March/April, 71-86.

GENERALITAT DE CATALUNYA (2002a) Catalonia. Learning, Creativity and Quality of Life at the Heart of the Mediterranean Arc. Departament d'Universitats, Recerca i Societat de la Informació, Generalitat de Catalunya, Barcelona.

GENERALITAT DE CATALUNYA (2002b) Les Empreses Catalanes a Ritme Europeu en l'Adopció de les TIC, Departament d'Universitats, Recerca i Societat de la Informació, Generalitat de Catalunya, Barcelona. 
http://dursi.gencat.net/pdf/si/observatori/np_TIC_empreses_2002.pdf [accessed June 2004]

GOLDEN BR (1992) The past is the past-or is it? The use of retrospective accounts as indicators of past strategy. Academic Management Journal 35, 848-860.

GRANDON E and PEARSON JM (2003) Strategic value and adoption of electronic commerce: an empirical study of Chilean small and medium businesses. Journal of Global Information Technology Management 6(3), 22-43.

GREENER I (2002) Theorising path-dependency: how does history come to matter in organisations? Journal of Management History 40(5/6), 614-619.

HARRISON DA, MYKYTYN PP and RIEMENSCHNEIDER CK (1997) Executive decisions about IT adoption in small business: theory and empirical tests. Information Systems Research 8(2), 171-195.

HARVIE C and LEE B (2002) Globalisation and Small and Medium Enterprises in East Asia. Edward Elgar, Cheltenham, UK.

IACOVOU CL, BENBASAT I and DEXTER AS (1995) Electronic data interchange and small organisations: adoption and impact of technology. MIS Quarterly 19(4), 465-485.

IBBOTSON F and FAHY M (2004) The impact of e-commerce on small Irish firms. International Journal of Services Technology and Management 5(4), 317-332.

KEELING K, VASSILOPOULOU K, McGOLDRICK P and MACAULAY L (2000) Market realities and innovation in small to medium enterprises: facilitators and barriers to the use of electronic commerce. New Product Development and Innovation Management 2(1), 57-70.

KENDALL J, TUNG LL, CHUA KH, NG CH and TAN SM (2001) Electronic commerce adoption by SMEs in Singapore. In Proceedings of the $34^{\text {th }}$ Annual Hawaii International Conference on System Sciences (HICSS-34), January 3-6, Hawaii, IEEE Computer Society Press, 10 pages.

LERTWONGSATIEN C and WONGPINUNWATANA N (2003) E-commerce adoption in Thailand: an empirical study of small and medium enterprises. Journal of Global Information Technology Management 6(3), 67-83.

LEVY M and POWELL P (2000) Information systems strategy for small and medium sized enterprises: an organisational perspective. Journal of Strategic Information Systems 9(1), 63-84. 
LEVY M and POWELL P (2003) Exploring SME Internet adoption: towards a contingent model. Electronic Markets 13(2), 173-181.

LOFORTE F and LOVE PED (2003) Value creation through an e-business strategy: implications for SMEs in construction. Construction Innovation 3(1), 3-14.

LONGENECKER JG, MOORE CW and PETTY JW (1994) Small Business Management: An Entrepreneurship Emphasis. Southwestern Publishing, Cincinnati.

MEHTA KT and SHAH V (2001) E-commerce: the next global frontier for small businesses. The Journal of Applied Business Research 17(1), 87-94.

MIRCHANDANI DA and MOTWANI J (2001) Understanding small business electronic commerce adoption: An empirical analysis. Journal of Computer Information Systems 41(3), 70-74.

MOODLEY S (2003) E-commerce and export markets: small furniture producers in South Africa. Journal of Small Business Management 41(3), 317-324.

MUSTAFFA S and BEAUMONT N (2004) The effect of electronic commerce on small Australian enterprises. Technovation 24(2), 85-95.

PALVIA PC (1995) A model and instrument for measuring small business user satisfaction with information technology. Information \& Management 31(3), 151163.

PERREN L and RAM M (2004) Case-study method in small businesses and entrepreneurial research: mapping boundaries and perspective. International Small Business Journal 22(1), 83-102.

POON S (2000) Business environment and Internet commerce benefit: a small business perspective. European Journal of Information Systems 9(2), 72-81.

POON S and HUANG C (2004) E-commerce and SMEs: a reflection and the way ahead. In Electronic Commerce in Small to Medium-Sized Enterprises: Frameworks, Issues, and Implications (Al-Qirim NAY, Ed), pp 17-29, Idea Group Publishing, Hershey, PA .

POON S and SWATMAN PMC (1999) An exploratory study of small business Internet commerce issues. Information and Management 35(1), 9-18.

RIEMENSCHNEIDER CK and McKINNEY VR (2001) Assessing belief differences in small business adopters and non-adopters of Web-based e-commerce. Journal of Computer Information Systems 42(2), 101-108.

ROGERS EM (1995) Diffusion of Innovation, $4^{\text {th }} \mathrm{ed}$. The Free Press, New York. 
SAUER C (1999) Deciding the future for IS failures: not the choice you might think. In Rethinking Management Information Systems (Galliers R and Currie WL, Eds), pp 279-309, Oxford University Press, Oxford.

SEYAL AH and RAHMAN MNA (2003) A preliminary investigation of e-commerce adoption in small and medium enterprises in Brunei. Journal of Global Information Technology Management 6(2), 8-23.

SILLINCE JAA, MacDONALD S, LEFANG B and FROST B (1998) Email adoption, diffusion, use and impact within small firms: a survey of UK companies. International Journal of Information Management 18(4), 231-242.

STOECKER R (1991) Evaluating and rethinking the case study. Sociological Review 39(1), 88-113.

THOMPSON VA (1965) Bureaucracy and innovation. Administrative Science Quarterly 5, 1-20.

THONG JYL (1999) An integrated model of information systems adoption in small businesses. Journal of Management Information Systems 15(4), 187-214.

TORNATZKY LG and FLEISCHER M (1990) The Processes of Technological Innovation, Lexington Books, Lexington, Massachusetts.

TRAVICA B (2002) Diffusion of electronic commerce in developing countries: the case of Costa Rica. Journal of Global Information Technology Management 5(1), $4-24$.

VAN AKKEREN JK and CAVAYE ALM (1999) Factors affecting entry-level Internet adoption by SMEs: an empirical study. In Proceedings of the 10th Australasian Conference in Information Systems, December 1-3, 1999, Wellington, New Zealand. http://www.vuw.ac.nz/acis99/ [accessed June 2005]

WEBB B and SAYER R (1998) Benchmarking small companies on the Internet. Long Range Planning 31(6), 815-827.

YIN RK (2003) Case Study Research: Design and Methods, $3^{\text {rd }}$ ed. Sage, London.

ZHU K and KRAEMER KL (2002) E-commerce metrics for net-enhanced organizations: assessing the value of e-commerce to firm performance in the manufacturing sector. Information Systems Research 13(3), 275- 296. 